\title{
An Examination of the Effects of Aerosol Chemical Composition and Size on Radiative Properties of Multi-Component Aerosols
}

\author{
Shaocai Yu*, Yang Zhang \\ Department of Marine, Earth, and Atmospheric Sciences, North Carolina State University, Raleigh, USA \\ E-mail:yu.shaocai@epa.gov \\ Received April 11, 2011; revised April 18, 2011; accepted April 19, 2011
}

\begin{abstract}
The sensitivity of aerosol radiative properties (i.e., scattering coefficient, extinction coefficient, single scatter albedo, and asymmetry factor) and radiation transmission to aerosol composition, size distributions, and relative humidity $(\mathrm{RH})$ is examined in this paper. Mie calculations and radiation calculations using a tropospheric visible radiation model are performed. The aerosol systems considered include inorganic and organic ions (e.g., $\mathrm{Cl}^{-}, \mathrm{Br}^{-}, \mathrm{NO}_{3}^{-}, \mathrm{SO}_{4}^{2-}, \mathrm{Na}^{+}, \mathrm{NH}_{4}^{+}, \mathrm{K}^{+}, \mathrm{Ca}^{2+}, \mathrm{Mg}^{2+}, \mathrm{HCOO}^{-}, \mathrm{CH}_{3} \mathrm{COO}^{-}, \mathrm{CH}_{3} \mathrm{CH}_{2} \mathrm{COO}^{-}$, $\mathrm{CH}_{3} \mathrm{COCOO}^{-}, \mathrm{OOCCOO}^{2-}, \mathrm{MSA}^{1-}$ ), and water-insoluble inorganic and organic compounds e.g., (black carbon, $n$-alkanes, $\mathrm{SiO}_{2}, \mathrm{Al}_{2} \mathrm{O}_{3}, \mathrm{Fe}_{2} \mathrm{O}_{3}$ and other organic compounds). The partial molar refraction method and the volume-average method are used to calculate the real and imaginary parts of refractive index of real aerosols, respectively. The sensitivity simulations show that extinction coefficient increases by $70 \%$ when RH varies from 0 to $80 \%$. Both extinction coefficient and asymmetry factor increase by $\sim 48 \%$ when real part varies from 1.40 to 1.65 . Scattering coefficient and single scattering albedo decrease by $18 \%$ and $24 \%$, respectively, when the imaginary part varies from -0.005 to -0.1 . Scattering and extinction coefficients increase by factors of 118 and 123, respectively, when the geometric mean radius varies from 0.05 to $0.3 \mu \mathrm{m}$. Scattering and extinction coefficients and asymmetry factor increase by factors of 389, 334, and 5.4, respectively, when geometric standard deviation varies from 1.2 to 3.0. The sensitivity simulations using a tropospheric visible radiation model show that the radiation transmission is very sensitive to the change in geometric mean radius and standard deviation; other factors are insignificant.
\end{abstract}

Keywords: Radiative Properties, Sensitivity Study, Aerosol Composition, Aerosol Size Distribution, Multi-Component Aerosols

\section{Introduction}

Atmospheric aerosols may influence the Earth's radiation balance directly by backscattering and absorption of solar radiation, and indirectly by increasing cloud condensation nuclei $(\mathrm{CCN})$ concentrations, which in turn increase cloud droplet concentrations and thus backscattering of solar radiation [1-3]. The IPCC [4] concluded that increasing concentrations of the long-lived greenhouse gases have led to a combined radiative forcing $+2.63[ \pm 0.26] \mathrm{W} \cdot \mathrm{m}^{-2}$, and the total direct aerosol radiative forcing is estimated to be -0.5 $[ \pm 0.4] \mathrm{W} \cdot \mathrm{m}^{-2}$, with a medium-low level of scientific

"Now at AMAD, NERL, U.S. EPA, RTP, NC 27711. understanding, while the radiative forcing due to the cloud albedo effect (also referred to as the first indirect effect), is estimated to be $-0.7[-1.1,+0.4] \mathrm{W} \cdot \mathrm{m}^{-2}$, with a low level of scientific understanding. Evaluation of aerosol direct radiative forcing is complicated by the fact that aerosols are highly and non-uniformly distributed over the Earth and comprise a variety of chemical species, and their abundance varies with particle size, location and time. As indicated by Penner et al. [5], one of central scientific questions related to the direct radiative influence of aerosols is how the aerosol composition and size distributions affect the optical depth and radiative properties of aerosols, including dependence on relative humidity. Up to today the sensitivity of di- 
rect aerosol forcing to chemical composition, size distribution and relative humidity on a global scale has been tested with a "reference box model" [1] and a GCM model [6-8] Most of these studies except for Jacobson (2001) on direct aerosol forcing only focused on anthropogenic sulfate aerosols. The objectives of this paper are 1) to accurately calculate the refractive index of aerosol particles with the known chemical composition of atmospheric aerosol; 2) to theoretically evaluate the sensitivity of aerosol radiative properties and radiation transmission in the visible range to refractive index, size distributions, and relative humidity $(\mathrm{RH})$ using a box model that includes Mie and radiative transfer calculation. Since the aerosol particle refractive index is determined by its chemical composition, the dependence of radiative properties of aerosol particles on the refractive index can indicate the effects of chemical composition. Since most of the light scattering and extinction are caused by particles in the accumulation mode size range $(0.1-1.0 \mu \mathrm{m}$, diameter $)$, and these particles are neither removed effectively by impaction nor by diffusion, the accumulation mode particles are the most important one in terms of aerosol radiative forcing. In this study the sensitivity of aerosol radiative properties to size distribution is examined on the basis of the calculation of the particle radiative properties for the accumulation mode only.

\section{Model Formulation}

\subsection{Atmospheric Aerosol Composition and Size Distribution}

Atmospheric aerosol particles are composed of complex mixtures of natural and anthropogenic chemical species that include 1) water-soluble inorganic and organic compounds such as sulfate, nitrate, formate and acetate, 2) water-insoluble inorganic and organic compounds such as black carbon, $\mathrm{Al}_{2} \mathrm{O}_{3}$ and $n$-alkanes, and 3) water itself. Soluble individual anion and cation concentrations of atmospheric aerosol are typically measured by Ion Chromatography (IC), and elements such as $\mathrm{Al}$ and $\mathrm{Pb}$ are determined by partially induced $\mathrm{X}$ ray emission (PIXE). On the other hand, the concentrations of insoluble high molecular weight organic compounds in aerosols are measured by gas-chromatography-masss pectrometer (GS/MS) method [9]. The IC and PIXE methods provide no information on the concentrations of specific salts or classes of inorganic and organic salts. The GC/MS method can quantify the concentrations of individual organic compounds in atmospheric particles. However, only about $10 \%$ of the total organic mass can be typically identified by the GC/MS method [9]. In gen- eral, the water-soluble materials within atmospheric aerosol particles are expected to be a mixture of different chemicals and the water soluble parts of aerosol particles are considered to be a mixture of electrolytes together with any other water-soluble material. There are possible interactions between those ions that do not commonly exist between chemical components, especially at high $\mathrm{RH}$ conditions [10]. For example, in a mixture of $\mathrm{KNO}_{3}$ and $\mathrm{NaCl}$, there is a possible interaction between $\mathrm{K}^{+}$and $\mathrm{Na}^{+}$. It is therefore reasonable to consider water-soluble parts of aerosol particles as a mixed solute, and aerosol particles at a dry state composed of mixed solute and insoluble substances. Since the composition of the aerosol particles depends on the sources and subsequent transformation while airborne, it is possible to separate aerosols into urban, rural continental and marine aerosols in a first approximation [11]. Table 1 provides the estimates of refractive index of chemical components for the three atmospheric aerosol types. The concentrations of inorganic compounds $\left(\mathrm{Cl}^{-}, \mathrm{Br}^{-}, \mathrm{NO}_{3}^{-}, \mathrm{SO}_{4}^{2-}, \mathrm{Na}^{+}\right.$, $\mathrm{NH}_{4}^{+}, \mathrm{K}^{+}, \mathrm{Ca}^{2+}, \mathrm{Mg}^{2+}, \mathrm{SiO}_{2}, \mathrm{Al}_{2} \mathrm{O}_{3}$, and $\mathrm{Fe}_{2} \mathrm{O}_{3}$ ), total concentrations of organics, and total mass concentrations of aerosol particles for three aerosol types were taken from the estimates of Pueschel [11]. For organics, over 80 individual organic compounds found in aerosol particles were identified and quantified previously [9]. In this study, the concentrations of soluble organic compounds $\left(\mathrm{HCOO}^{-}, \mathrm{CH}_{3} \mathrm{COO}^{-}, \mathrm{CH}_{3} \mathrm{CH}_{2} \mathrm{COO}^{-}, \mathrm{CH}_{3} \mathrm{COCOO}^{-}\right.$, $\mathrm{OOCCOO}^{2-}$, Methane sulfonic acid (MSA)) were taken from the estimates of $\mathrm{Yu}$ [2]. Chylek et al. [12] showed that the average black carbon (BC) atmospheric concentration in the continental air was $0.23 \pm 0.04 \mu \mathrm{g} / \mathrm{m}^{3}$ compared with $0.03 \pm 0.01 \mu \mathrm{g} / \mathrm{m}^{3}$ for the maritime air in the measurements over the southern Nova Scotia. Huntzicker et al. [13] indicated that the average BC concentration for 26 cities in the United State was $3.8 \mu \mathrm{g} / \mathrm{m}^{3}$. In this study, the $\mathrm{BC}$ concentrations used for urban, continental, and marine aerosols are 3.8, 0.23 and 0.06 $\mu \mathrm{g} / \mathrm{m}^{3}$, respectively. The other organic compound concentrations listed in Table 1 were taken from the estimates of Roggie et al. [9]. Table 2 lists the physical chemical and optical properties of various pure salts in atmospheric particles. For the aerosol model computation, a lognormal distribution function is suitable to characterize the size distribution of atmospheric aerosols [11]. Particles in the accumulation mode $(0.1-1.0 \mu \mathrm{m}$, aerodynamic diameter) are the most important one in terms of aerosol radiative forcing. Table $\mathbf{3}$ lists the typical size distributions for three types of aerosol for the accumulation mode at a dry state compiled from literatures. As shown, the total number concentration, the geometric mean diameter $\left(\mathrm{D}_{\mathrm{g}}\right)$, and the geometric standard deviation $\left(\sigma_{\mathrm{g}}\right)$ for the accumulation mode are in the ranges of 
Table 1. The aerosol chemical composition under different environments and their calculated refractive index (real part) (see text for explanation).

\begin{tabular}{|c|c|c|c|}
\hline \multirow[b]{2}{*}{ Species } & \multicolumn{3}{|c|}{ Aerosol type $\left(\mu \mathrm{g} / \mathrm{m}^{3}\right)$} \\
\hline & Urban & Continental & Marine \\
\hline \multicolumn{4}{|l|}{ Soluble component } \\
\hline $\mathrm{OH}^{-}$ & 0 & 0 & 0 \\
\hline $\mathrm{F}^{-}$ & 0 & 0 & 0 \\
\hline $\mathrm{Br}^{-}$ & 0.1 & 0.02 & 0.02 \\
\hline $\mathrm{Cl}^{-}$ & 3.2 & 0.11 & 4.6 \\
\hline $\mathrm{NO}_{3}^{-}$ & 3 & 0.9 & 0.05 \\
\hline $\mathrm{SO}_{4}^{2-}$ & 14 & 2.8 & 2.6 \\
\hline $\mathrm{Na}^{+}$ & 1.2 & 0.05 & 2.9 \\
\hline $\mathrm{NH}_{4}^{+}$ & 4.8 & 1.2 & 0.16 \\
\hline $\mathrm{K}^{+}$ & 0.4 & 0.06 & 0.1 \\
\hline $\mathrm{Ca}^{2+}$ & 1.6 & 0.17 & 0.2 \\
\hline $\mathrm{Mg}^{2+}$ & 0.6 & 0.09 & 0.4 \\
\hline $\mathrm{HCOO}^{-}$ & 0.108 & 0.045 & 0.025 \\
\hline $\mathrm{CH}_{3} \mathrm{COO}^{-}$ & 0.118 & 0.018 & 0.01 \\
\hline $\mathrm{CH}_{3} \mathrm{CH}_{2} \mathrm{COO}^{-}$ & 0 & 0 & 0 \\
\hline $\mathrm{CH}_{3}(\mathrm{CO}) \mathrm{COO}^{-}$(pyruvic) & 0 & 0 & 0 \\
\hline$(\mathrm{OOCCOO})^{2-}$ (oxalic) & 0.158 & 0.015 & 0.015 \\
\hline $\mathrm{CH}_{3} \mathrm{~S}(\mathrm{O})_{2} \mathrm{OH}(\mathrm{MSA})$ & 0.008 & 0.008 & 0.008 \\
\hline \multicolumn{4}{|l|}{ Insoluble component } \\
\hline BC (balck carbon) & 3.8 & 0.23 & 0.06 \\
\hline $\mathrm{SiO}_{2}$ & 5.9 & 0.7 & 0 \\
\hline $\mathrm{Al}_{2} \mathrm{O}_{3}$ & 3.6 & 0.24 & 0 \\
\hline $\mathrm{Fe}_{2} \mathrm{O}_{3}$ & 5.3 & 0.22 & 0.07 \\
\hline $\mathrm{CH}_{3}\left(\mathrm{CH}_{2}\right)_{14} \mathrm{COOH}(\mathrm{n}$-Hexadecanoic acid) & 0.118 & 0.014 & 0.014 \\
\hline $\mathrm{CH} 3(\mathrm{CH} 2)_{16} \mathrm{COOH}(\mathrm{n}$-Octadecanoic acid) & 0.057 & 0.002 & 0.002 \\
\hline $\mathrm{HOOCCH}_{2} \mathrm{COOH}$ (Malonic acid) & 0.028 & $<0.00001$ & $<0.00001$ \\
\hline $\mathrm{HOOC}\left(\mathrm{CH}_{2}\right)_{2} \mathrm{COOH}($ Succinic acid $)$ & 0.055 & $<0.00001$ & $<0.00001$ \\
\hline $\mathrm{HOOC}\left(\mathrm{CH}_{2}\right)_{3} \mathrm{COOH}($ Glutaric acid $)$ & 0.028 & $<0.00002$ & $<0.00002$ \\
\hline $\mathrm{C}_{6} \mathrm{H}_{4}(\mathrm{COOH})_{2}(1,2$-Benzenedicarxylic acid $)$ & 0.06 & $<0.00002$ & $<0.00002$ \\
\hline other organic compounds & 26 & 0.9 & 0.8 \\
\hline Total organic mass $\left(\mu \mathrm{g} / \mathrm{m}^{3}\right)$ & 30.6 & 1.17 & 0.9 \\
\hline Total inorganic mass $\left(\mu \mathrm{g} / \mathrm{m}^{3}\right)$ & 43.5 & 6.4 & 11.2 \\
\hline Total mass $\left(\mu \mathrm{g} / \mathrm{m}^{3}\right)$ & 74.24 & 7.79 & 12.03 \\
\hline Mean density $\left(\mu \mathrm{g} / \mathrm{m}^{3}\right)$ & 1.82 & 1.89 & 1.825 \\
\hline Refractive index for aerosol particles & 1.59 & 1.564 & 1.479 \\
\hline
\end{tabular}

18.6 to $3000 \mathrm{~cm}^{-3}, 0.076$ to $0.75 \mu \mathrm{m}$, and 1.35 to 2.0 , respectively.

\subsection{The Effect of Relative Humidity}

Table 2 lists the RH at which the deliquescence will occur for some pure salts (RHD). The effects of continuously increasing $\mathrm{RH}$ on the growth of a pure salt aerosol particle can be calculated from equilibrium thermodynamics [10]. However, it is very difficult to predict this so-called "hysteresis effects" of water uptake for actual multi-component aerosol particles because this not only depends on the history of RH but also varies from one sample to another [10]. Here, the particle hysteresis effects should not be considered in detail. Instead, the density, refractive index, and radius of aerosol particles are 
Table 2. The physical-chemical and optical properties of different salts in atmospheric aerosol particles. RHD is the RH of deliquescence (see text for explanations).

\begin{tabular}{|c|c|c|c|c|c|c|c|}
\hline Salts & $\begin{array}{l}\text { Refractive } \\
\text { Index }\end{array}$ & $\begin{array}{l}\text { Density } \\
\left(\mathrm{g} \cdot \mathrm{cm}^{-3}\right)\end{array}$ & RHD(\%) & Salts & $\begin{array}{l}\text { Refractive } \\
\text { Index }\end{array}$ & $\begin{array}{l}\text { Density } \\
\left(\mathrm{g} \cdot \mathrm{cm}^{-3}\right)\end{array}$ & $\begin{array}{l}\text { RHD } \\
(\%)\end{array}$ \\
\hline $\mathrm{NH}_{4} \mathrm{CH}_{3} \mathrm{COO}$ & & 1.174 & & $\mathrm{Mg}\left(\mathrm{CH}_{3} \mathrm{COO}\right)_{2}\left(\mathrm{H}_{2} \mathrm{O}\right)_{4}$ & 1.491 & 1.454 & \\
\hline $\mathrm{NH}_{4} \mathrm{Br}$ & 1.712 & 2.429 & & $\mathrm{MgBr}_{2}$ & & 3.724 & \\
\hline $\mathrm{NH}_{4} \mathrm{HCO}_{3}$ & 1.423 & 1.580 & & $\mathrm{MgCO}_{3}$ & 1.717 & 2.958 & \\
\hline $\mathrm{NH}_{4} \mathrm{Cl}$ & 1.642 & 1.527 & 80 & $\mathrm{MgCO}_{3}\left(\mathrm{H}_{2} \mathrm{O}\right)_{5}$ & 1.456 & 1.730 & \\
\hline $\mathrm{NH}_{4} \mathrm{~F}$ & & 1.009 & & $\mathrm{MgCl}_{2}$ & 1.675 & 2.320 & \\
\hline $\mathrm{NH}_{4} \mathrm{NO}_{3}$ & & 1.725 & 62 & $\mathrm{MgCl}_{2}\left(\mathrm{H}_{2} \mathrm{O}\right)_{6}$ & 1.495 & 1.569 & \\
\hline$\left(\mathrm{NH}_{4}\right)_{2} \mathrm{SO}_{4}$ & 1.521 & 1.769 & 80 & $\mathrm{Mg}\left(\mathrm{NO}_{3}\right)_{2}\left(\mathrm{H}_{2} \mathrm{O}\right)_{6}$ & & 1.636 & \\
\hline $\mathrm{NH}_{4} \mathrm{HSO}_{4}$ & 1.473 & 1.780 & 40 & $\mathrm{MgSO}_{4}$ & 1.560 & 2.660 & \\
\hline $\mathrm{Ca}\left(\mathrm{CH}_{3} \mathrm{COO}\right)_{2}$ & 1.550 & & & $\mathrm{MgSO}_{4}\left(\mathrm{H}_{2} \mathrm{O}\right)_{7}$ & 1.433 & 1.680 & \\
\hline $\mathrm{Ca}(\mathrm{Br})$ & & 3.353 & & $\mathrm{MgSO}_{4}\left(\mathrm{H}_{2} \mathrm{O}\right)$ & 1.523 & 2.445 & \\
\hline $\mathrm{CaCO}_{3}$ & 1.658 & 2.710 & & $\mathrm{KBr}$ & 1.559 & 2.750 & 84 \\
\hline $\mathrm{CaCO}_{3}\left(\mathrm{H}_{2} \mathrm{O}\right)_{6}$ & 1.460 & 1.771 & & $\mathrm{~K}_{2} \mathrm{CO}_{3}$ & 1.531 & 2.428 & 43 \\
\hline $\mathrm{CaCl}_{2}$ & 1.520 & 2.150 & 32 & $\mathrm{~K}_{2} \mathrm{CO}_{3}\left(\mathrm{H}_{2} \mathrm{O}\right)_{2}$ & 1.380 & 2.043 & 43 \\
\hline $\mathrm{CaCl}_{2}\left(\mathrm{H}_{2} \mathrm{O}\right)_{6}$ & 1.417 & 1.710 & & $\mathrm{KHCO}_{3}$ & 1.482 & 2.170 & \\
\hline $\mathrm{Ca}(\mathrm{HCOO})_{2}$ & 1.510 & 2.015 & & $\mathrm{KCl}$ & 1.490 & 1.984 & 88 \\
\hline $\mathrm{Ca}\left(\mathrm{NO}_{3}\right)_{2}\left(\mathrm{H}_{2} \mathrm{O}\right)_{4}$ & 1.465 & 1.896 & & $\mathrm{KF}$ & 1.363 & 2.480 & \\
\hline $\mathrm{CaSO}_{4}$ & 1.505 & 2.610 & & $\mathrm{KF}\left(\mathrm{H}_{2} \mathrm{O}\right)_{2}$ & 1.352 & 2.454 & \\
\hline $\mathrm{CaSO}_{4}\left(\mathrm{H}_{2} \mathrm{O}\right)_{2}$ & 1.521 & 2.320 & & $\mathrm{~K}_{2} \mathrm{SO}_{4}$ & 1.494 & 2.662 & \\
\hline $\mathrm{NaCH}_{3} \mathrm{COO}$ & 1.464 & 1.528 & 78 & $\mathrm{KHSO}_{4}$ & 1.480 & 2.322 & 86 \\
\hline $\mathrm{NaBr}$ & 1.641 & 3.203 & 58 & $\mathrm{~Pb}$ & 2.010 & 11.344 & \\
\hline $\mathrm{Na}_{2} \mathrm{CO}_{3}$ & 1.535 & 2.532 & 90 & $\mathrm{BC}$ & 2.000 & 2.250 & \\
\hline $\mathrm{Na}_{2} \mathrm{CO}_{3}\left(\mathrm{H}_{2} \mathrm{O}\right)_{10}$ & 1.405 & 1.440 & & $\mathrm{O}_{3}$ & 1.223 & & \\
\hline $\mathrm{NaHCO}_{3}$ & 1.500 & 2.159 & & $\mathrm{SiC}$ & 2.654 & 3.217 & \\
\hline $\mathrm{NaCl}$ & 1.544 & 2.165 & 75.3 & $\mathrm{SiO}_{2}$ & 1.487 & 2.320 & \\
\hline $\mathrm{NaF}$ & 1.336 & 2.558 & & $\mathrm{H}_{2} \mathrm{SO}_{4}\left(\mathrm{H}_{2} \mathrm{O}\right)_{2}$ & 1.405 & & \\
\hline $\mathrm{NaNO}_{3}$ & 1.587 & 2.261 & 74.5 & $\mathrm{PbCl}_{2}$ & 2.199 & 5.850 & \\
\hline $\mathrm{Na}_{2} \mathrm{SO}_{4}$ & 1.484 & 2.680 & 84 & $\mathrm{Fe}_{2} \mathrm{O}_{3}$ & 3.220 & 5.240 & \\
\hline $\mathrm{Na}_{2} \mathrm{SO}_{4}\left(\mathrm{H}_{2} \mathrm{O}\right)_{10}$ & 1.394 & 2.680 & 84 & $\mathrm{Al}_{2} \mathrm{O}_{3}$ & 1.768 & 3.965 & \\
\hline $\mathrm{NaHSO}_{4}\left(\mathrm{H}_{2} \mathrm{O}\right)$ & 1.460 & 2.476 & 52 & $\mathrm{PbO}$ & 2.510 & 8.000 & \\
\hline $\mathrm{CH}_{3} \mathrm{CHO}$ & 1.332 & 0.783 & & $\mathrm{H}_{2} \mathrm{O}$ & 1.333 & 1.000 & \\
\hline $\mathrm{CH}_{3}\left(\mathrm{CH}_{2}\right)_{14} \mathrm{COOH}$ & 1.433 & 0.853 & & $\mathrm{CH}_{3}\left(\mathrm{CH}_{2}\right)_{14} \mathrm{COOH}$ & 1.434 & 0.853 & \\
\hline $\mathrm{CH}_{3}\left(\mathrm{CH}_{2}\right)_{16} \mathrm{COOH}$ & 1.422 & 0.941 & & formic acid & 1.371 & 1.220 & \\
\hline $\mathrm{HOOCCH}_{2} \mathrm{COOH}$ & & 1.619 & & acetic acid & 1.372 & 1.049 & \\
\hline $\mathrm{HOOC}\left(\mathrm{CH}_{2}\right)_{2} \mathrm{COOH}$ & 1.450 & 1.572 & & pyruvic acid & 1.428 & 1.227 & \\
\hline $\mathrm{HOOC}\left(\mathrm{CH}_{2}\right)_{3} \mathrm{COOH}$ & 1.419 & 1.424 & & oxalic acid & & 1.900 & \\
\hline $\mathrm{C}_{6} \mathrm{H}_{4}(\mathrm{COOH})_{2}$ & 1.431 & 1.462 & & & & & \\
\hline Other organics & 1.550 & 1.400 & & & & & \\
\hline
\end{tabular}

considered as a unique function of RH in which the "hysteresis effects" are partially taken into account for three aerosol types using the experimental data of Hänel [10]:

$$
\rho=\rho_{w}+\left(\rho_{0}-\rho_{w}\right)\left(1+\frac{\rho_{0}}{\rho_{w}} \bar{\mu} \frac{R H}{1-R H}\right)^{-1}
$$


Table 3. Scattering and extinction coefficients, asymmetry factor and single scattering albedo and their growth factor for selected aerosol types. Scattering coefficient $\left(\sigma_{\mathrm{sp}}, \mathrm{km}^{-1}\right)$, extinction coefficient $\left(\sigma_{\mathrm{ep}}, \mathrm{km}^{-1}\right)$, asymmetry factor $(\mathrm{g})$ and single scattering albedo $(\omega)$. The indices $1,2,3$ represent the values at $\mathbf{R H}=30 \%, 80 \%$ and $99 \%$, respectively. Read $\frac{\sigma_{s p 2}}{\sigma_{s p 1}}$ as ratio of scattering coefficient at $\mathbf{R H}=\mathbf{8 0} \%$ to that at $\mathbf{R H}=\mathbf{3 0} \%$.

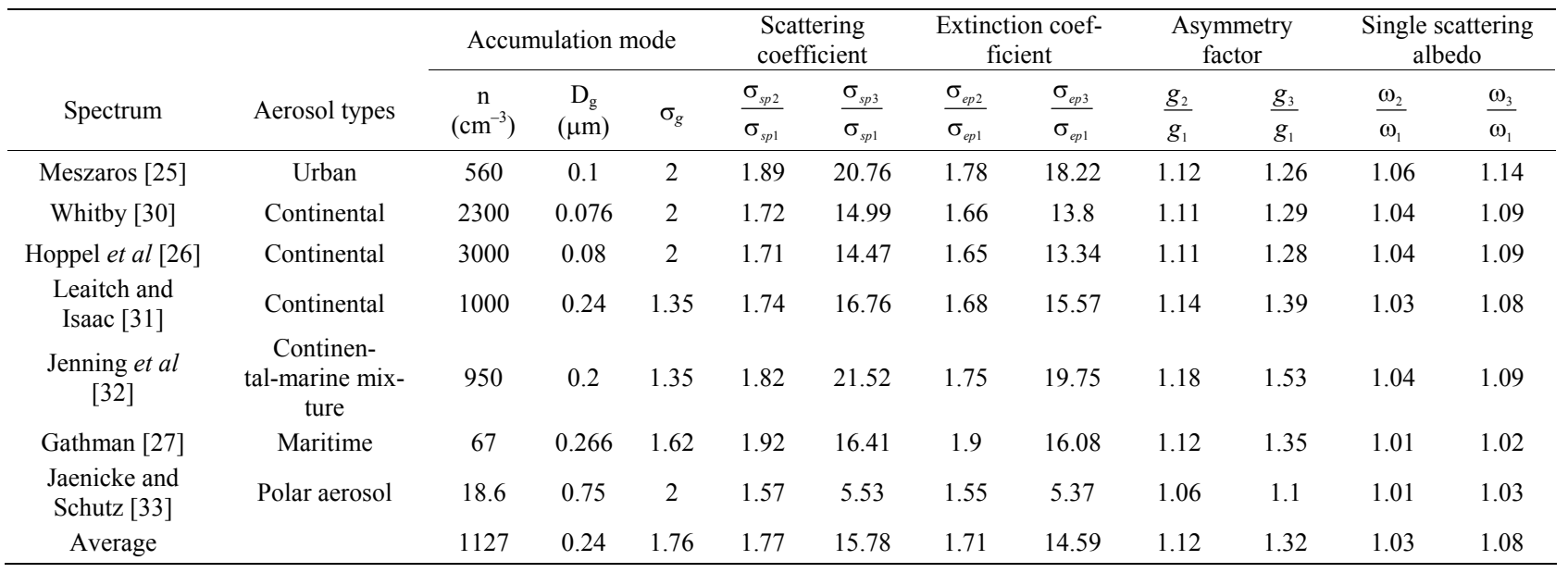

$$
\begin{aligned}
& m_{r}=m_{r w}+\left(m_{r 0}-m_{r w}\right)\left(1+\frac{\rho_{0}}{\rho_{w}} \bar{\mu} \frac{R H}{1-R H}\right)^{-1} \\
& m_{i}=m_{i w}+\left(m_{i 0}-m_{i w}\right)\left(1+\frac{\rho_{0}}{\rho_{w}} \bar{\mu} \frac{R H}{1-R H}\right)^{-1} \\
& r=r_{0}\left(1+\frac{\rho_{0}}{\rho_{w}} \bar{\mu} \frac{R H}{1-R H}\right)^{-1}
\end{aligned}
$$

where the subscript " $w$ " denotes pure water and " 0 " indicates the dry substance, $m_{r}$ and $m_{i}$ are the real and imaginary parts of refractive index. $\bar{\mu}$ is mean linear mass increase coefficient. Figure 1 shows $\bar{\mu}$ as a function of $\mathrm{RH}$ for three aerosol types, which are obtained from the experimental results in Table 4 of Hänel [10]. As shown, the dependence of $\bar{\mu}$ on $\mathrm{RH}$ for difference types of aerosols is rather complicated. RH can affect radiative properties of aerosol particles through changing particle size and refractive index. Figure 2 shows the changes of densities, refractive indices, and radius for three type aerosols as a function of RH. As shown, the $\mathrm{RH}$ effect is important at $\mathrm{RH}>80 \%$ for density and refractive index, but the radius is sensitive to the change in RH only when RH $>90 \%$.

\section{Results and Discussions}

\subsection{Refractive Index Calculation}

One of central questions for prediction of radiative properties of aerosol particles is to accurately calculate their refractive indices. As shown in Table 1, the available

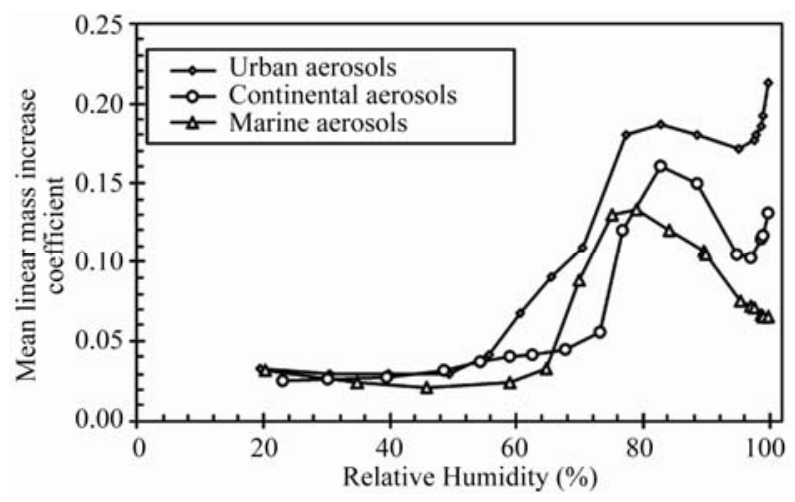

Figure 1. Mean linear mass increase coefficient $(\bar{\mu})$ as a function of relative humidity for three types of aerosols (Maritime aerosols over the Atlantic, 13-16 April, 1969; Urban aerosols at Mainz, January, 1970; Continental aerosols on top of the Hohenpeissenberg, $1000 \mathrm{~m}$ mean sea level (MSL), summer, 1970) [10].

information on the particle compositions is the ion concentrations of soluble components and compound concentrations of insoluble components. It has been shown that the partial molar refraction approach is applicable to calculate refractive indices for ionic solid-aqueous electrolyte mixtures [14]. The partial molar refraction $R$ $\left(\mathrm{cm}^{3} \cdot \mathrm{mol}^{-1}\right)$ is defined as [15]:

$$
R=\frac{n^{2}-1}{n^{2}+2}\left(\frac{M}{\rho}\right)
$$

where $n$ is refractive index, $M$ is molecular weight, and $\rho$ is density $\left(\mathrm{g} \cdot \mathrm{cm}^{-3}\right)$. If the molar refractions of components are known, the mean refractive index of a 
Table 4. The partial molar refraction of aerosol chemical components. MH [29] is Moelwyn-Hughes [29].

\begin{tabular}{|c|c|c|c|c|}
\hline & Species & $\begin{array}{c}\text { Partial molar } \\
\text { refraction }\left(\mathrm{Ri}, \mathrm{cm}^{-3}\right) \\
\end{array}$ & $\mathrm{Ri} / \mathrm{Mi}$ & Reference \\
\hline & \multicolumn{4}{|l|}{ Soluble components } \\
\hline 1 & $\mathrm{H}^{+}$ & 0 & 0 & MH [29] \\
\hline 2 & $\mathrm{OH}^{-}$ & 4.43 & 0.261 & MH [29] \\
\hline 3 & $\mathrm{~F}^{-}$ & 2.17 & 0.114 & MH [29] \\
\hline 4 & $\mathrm{Br}^{-}$ & 11.84 & 0.148 & Stelson [14] \\
\hline 5 & $\mathrm{Cl}^{-}$ & 8.39 & 0.237 & Stelson [14] \\
\hline 6 & $\mathrm{NO}_{3}^{-}$ & 10.19 & 0.164 & MH [29] \\
\hline 7 & $\mathrm{SO}_{4}^{2-}$ & 13.45 & 0.14 & Stelson [14] \\
\hline 8 & $\mathrm{Na}^{+}$ & 0.93 & 0.04 & Stelson [14] \\
\hline 9 & $\mathrm{NH}_{4}^{+}$ & 4.89 & 0.271 & Stelson [14] \\
\hline 10 & $\mathrm{~K}^{+}$ & 3.03 & 0.078 & Stelson [14] \\
\hline 11 & $\mathrm{Ca}^{2+}$ & 1.93 & 0.048 & Stelson [14] \\
\hline 12 & $\mathrm{Mg}^{2+}$ & 0.03 & 0.001 & Stelson [14] \\
\hline 13 & $\mathrm{HCOO}^{-}$ & 7.27 & 0.161 & This work \\
\hline 14 & $\mathrm{CH}_{3} \mathrm{COO}^{-}$ & 12.94 & 0.219 & This work \\
\hline 15 & $\mathrm{CH}_{3} \mathrm{CH}_{2} \mathrm{COO}^{-}$ & 17.59 & 0.241 & This work \\
\hline 16 & $\mathrm{CH}_{3}(\mathrm{CO}) \mathrm{COO}^{-}$(pyruvic) & 17.65 & 0.203 & This work \\
\hline 17 & $(\mathrm{OOCCOO})^{2-}$ (oxalic) & 14.53 & 0.165 & This work \\
\hline 18 & $\mathrm{CH}_{3} \mathrm{~S}(\mathrm{O})_{2} \mathrm{OH}(\mathrm{MSA})$ & 16.82 & 0.175 & This work \\
\hline \multirow[t]{2}{*}{19} & $\mathrm{H}_{2} \mathrm{O}$ & 3.71 & 0.206 & Stelson [14] \\
\hline & insoluble component & & & \\
\hline 20 & $\mathrm{BC}$ & 2.11 & 0.176 & This work \\
\hline 21 & $\mathrm{SiO}_{2}$ & 7.43 & 0.124 & Stelson [14] \\
\hline 22 & $\mathrm{Al}_{2} \mathrm{O}_{3}$ & 10.62 & 0.104 & Stelson [14] \\
\hline 23 & $\mathrm{Fe}_{2} \mathrm{O}_{3}$ & 22.21 & 0.139 & Stelson [14] \\
\hline 24 & $\mathrm{PbO}$ & 18.4 & 0.082 & Stelson [14] \\
\hline 25 & $\mathrm{~Pb}$ & 9.24 & 0.045 & Stelson [14] \\
\hline 26 & $\mathrm{CH}_{3}\left(\mathrm{CH}_{2}\right)_{14} \mathrm{COOH}$ (n-Hexadecanoic acid) & 78 & 0.305 & This work \\
\hline 27 & $\mathrm{CH}_{3}\left(\mathrm{CH}_{2}\right)_{16} \mathrm{COOH}$ (n-Octadecanoic acid) & 87.29 & 0.307 & This work \\
\hline 28 & $\mathrm{HOOCCH}_{2} \mathrm{COOH}$ (Malonic acid) & 17.24 & 0.166 & This work \\
\hline 29 & $\mathrm{HOOC}\left(\mathrm{CH}_{2}\right)_{2} \mathrm{COOH}$ (Succinic acid) & 24.2 & 0.205 & This work \\
\hline 30 & $\mathrm{HOOC}\left(\mathrm{CH}_{2}\right)_{3} \mathrm{COOH}$ (Glutaric acid) & 28.47 & 0.216 & This work \\
\hline 31 & $\mathrm{C}_{6} \mathrm{H}_{4}(\mathrm{COOH})_{2}$ & 39.99 & 0.241 & This work \\
\hline 32 & other organic compound & 50 & 0.24 & This work \\
\hline
\end{tabular}

medium can be calculated as follows [15]:

$$
n=\left[\frac{1+2 \frac{R}{V}}{1-\frac{R}{V}}\right]^{\frac{1}{2}}
$$

for an aerosol particle:

$$
\frac{R}{V}=\frac{\sum\left(\frac{R_{i}}{M_{i}}\right)\left[\mathrm{C}_{i}\right]}{[A V]}
$$

where $R_{i}$ is the partial molar refraction of component $i$ in $\mathrm{cm}^{3} \cdot \mathrm{mol}^{-1}, M_{i}$ is the molecular weight of component $i$ in $\mathrm{g} \cdot \mathrm{mol}^{-1},\left[C_{i}\right]$ is the concentration of component $i$ in $\mu \mathrm{g} \cdot \mathrm{m}^{-3}$, and $[\mathrm{AV}]$ is the aerosol volume in $\mu \mathrm{g} \cdot \mathrm{m}^{-3}$. The aerosol volume can be either measured or predicted by:

$$
[A V]=\sum \frac{\mathrm{C}_{i}}{\rho_{i}}
$$

where $\rho_{i}$ is the density of component $i$ in $\mathrm{g} \mathrm{cm}^{-3}$. Table 4 

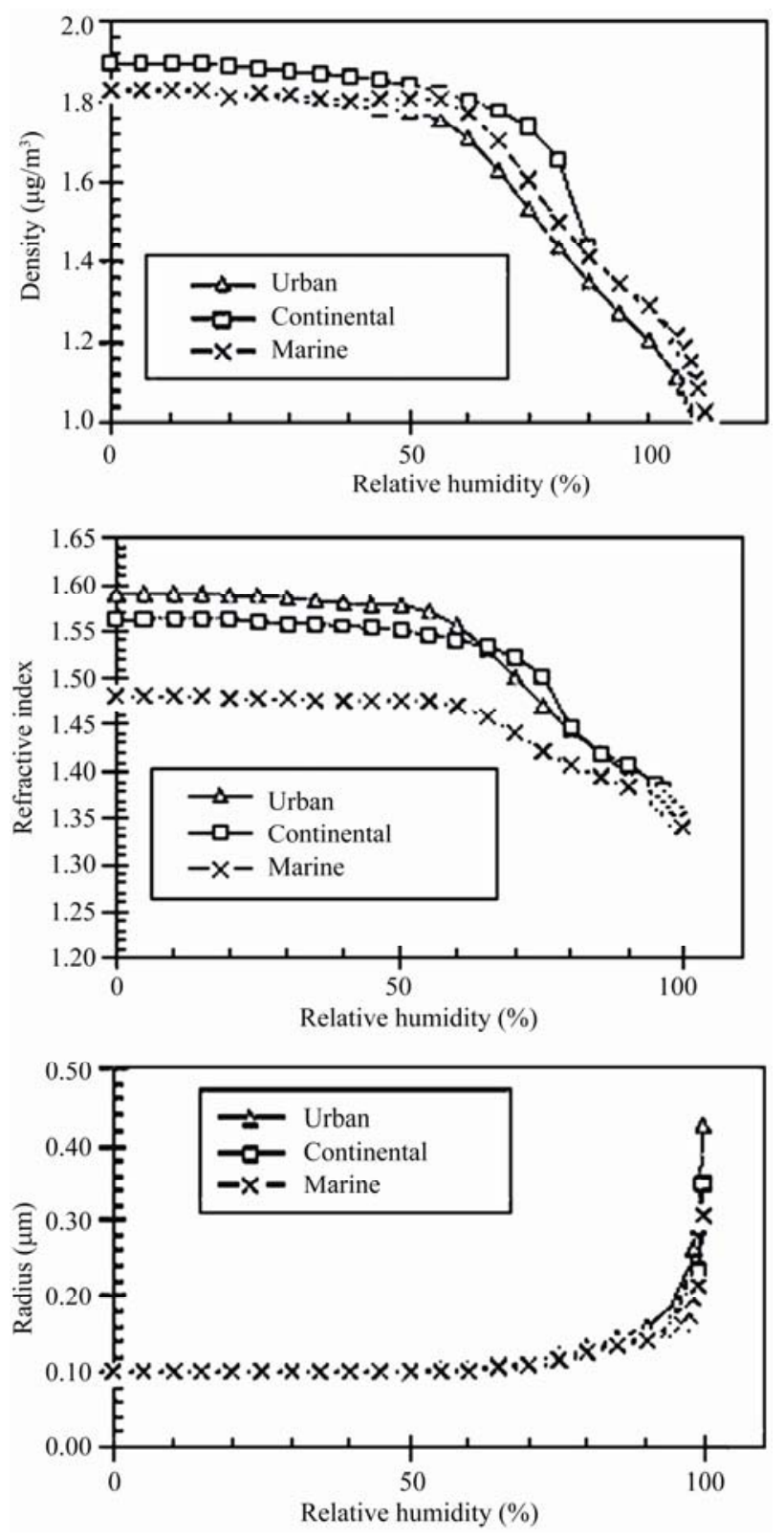

Figure 2. Density, refractive index, and radius as a function of RH for three types of aerosols.

lists the partial molar refractions for ions. Table 2 contains the refractive index and density for possible salts found in atmospheric aerosol particles. The refractive index and density for most compounds in aerosol particles range from 1.332 to 2.654 and from 0.783 to 11.344 $\mathrm{g} \cdot \mathrm{cm}^{-3}$, respectively. Volz [16] reported densities of water-soluble materials from different rainfalls and locations to be in a range of $1.76-1.96 \mathrm{~g} \cdot \mathrm{cm}^{-3}$. In this study, the average value $\left(1.86 \mathrm{~g} \cdot \mathrm{cm}^{-3}\right)$ is used as the mean density for water-soluble parts in aerosol particles. The density $\left(1.40 \mathrm{~g} \cdot \mathrm{cm}^{-3}\right)$ and refractive index $(1.55)$ for other organic compounds in Table 2 were taken from the estimates of Sloane [17]. Additionally, the mean aerosol density, $\rho$, can be calculated from: $\rho=\frac{\sum s_{i}}{\sum \frac{s_{i}}{\rho_{i}}}$.

In this study, the above partial molar refraction approach is extended to calculate the refractive index of any atmospheric particles with the known chemical compositions. Table 4 lists the partial molar refraction for other aerosol components including insoluble inorganic and organic compounds, which were calculated based on the method of Weast [15]. In this study, an internal mixture is assumed for atmospheric aerosol components. Tang [16] showed that both internal and external mixtures exhibited similar light-scattering properties. Table 1 lists the values of refractive index and mean density for three typical aerosol types calculated by the partial molar refractive approach. The mean densities for three aerosol types at the dry state range from 1.803 to $1.890 \mathrm{~g} / \mathrm{m}^{3}$. The real parts of refractive index for urban, continental, and marine aerosols are $1.575,1.557$ and 1.479 , respectively. As reviewed by Horvath [19], only black carbon (BC, the main constituent of soot) in atmospheric aerosol particles is highly absorbed. Hematite $\left(\mathrm{a}-\mathrm{Fe}_{2} \mathrm{O}_{3}\right)$ is the only other substance having a light absorption comparable to EC in the near suggest to use full name of "UV", u. v., but absorption rapidly decreases in the visible spectrum of the light. There are some discrepancies about the value of the complex refractive index of EC because of the difficulty of its experimental determination. The values given in the literature range from 1.2 to 2.0 for the real part and from -0.1 to -1.0 for the complex part [19]. In this study, the refractive index used for EC is 2.0 $0.66 i$. Since the imaginary parts for all ions in Table 1 are zero and the densities of each ion in Table1 are not known, it is not easy to calculate the partial mole refractions of the ions for imaginary parts using the definition Equation (5). In this study, the imaginary part of muticomponent aerosols is calculated using the volume average of the imaginary parts of refractive index of the individual species, $\bar{m}_{i}$, as follows [17]:

$$
\overline{m_{i}}=\left[\sum m_{i} \frac{s_{i}}{\rho_{i}}\right]\left[\sum \frac{s_{i}}{\rho_{i}}\right]^{-1}
$$

where $m_{i}$ is the imaginary part of refractive index of component $i$. With the estimates of $\mathrm{BC}$ concentration for three types of aerosols in Table 1, it was found that the complex refractive indices for urban, continental and marine aerosols are $1.575-0.027 i, 1.557-0.016 i, 1.479$ $-0.0027 i$, respectively. Hänel [10] found that the real part of refractive index for urban aerosols in the city of Mainz, Germany, was $1.57 \pm 0.04$ by actual measurement. Grams et al. [20] determined that the complex re- 
fractive index for urban aerosols in the city of Boulder, Colorado O, was $1.55-0.044 i$ on the basis of light scattering measurements. The results from this study are very close to these actual measurements. These complex refractive indices for three types of aerosols will be used in the calculation hereafter.

\subsection{The Sensitivity to Relative Humidity}

A Mie theory computer code developed by Dave [21] is used in this study to compute aerosol radiative properties. All aerosol particles are assumed to be spherical in shape in the calculation. Table 3 shows the values of the particle light scattering and extinction coefficients calculated with the above assumption at RHs of $30 \%, 80 \%$ and $99 \%$ for different particle size distributions of several aerosol types at a wavelength of $580 \mathrm{~nm}$. The wavelength, 580 $\mathrm{nm}$, is chosen based on the recommendation by Horvath [19] to give the maximum perception of an object under the daylight conditions. As shown, the growth factors for an $\mathrm{RH}$ range of 30 to $80 \% \mathrm{RH}$ range from 1.57 to 1.92 (average $1.77 \pm 0.12$ ) and from 1.55 to 1.90 (average $1.77 \pm 0.11$ ) for scattering and extinction coefficients, respectively. This is in agreement with the criterion value of the hydroscopic growth factor $(1.7 \pm 0.3)$ (which is defined as the ratio of the light scattering coefficient by an aerosol at an $\mathrm{RH}$ of $80 \%$ to that at $30 \%$ ) derived from the direct nephelometer measurement [22]. This value has been utilized to date as the first estimate in climate change modeling studies [1]. It is interesting to note that Hegg et al. [23] obtained substantially larger values of the hygroscopic growth (see Table 1 of Hegg et al. [23]) for the same size distribution as those in Table 3. Hegg et al. [23] attributed it to be influenced by the position of the initial dry aerosol size distribution relative to the effective light scattering droplet size range. The main differences in our calculation results and those of Hegg et al. [23] lie in different values of the refractive index and mean linear mass increase coefficient used for aerosol particles. The consistence of our results in Table 3 with the range of hygroscopic growth factor (1.5 to 1.8) from the direct measurements of Charlson et al. [22] indicates that our calculation for the effects of $\mathrm{RH}$ on scattering coefficient is reasonable. At a high $\mathrm{RH}$ such as $99 \%$, the growth factors are much higher and more variable than values at lower RHs as shown in Table 4. The growth factors range from 1.06 to 1.18 (average $1.12 \pm 0.04$ ) and from 1.10 to 1.53 (average $1.32 \pm 0.13$ ) for asymmetry factor in the $\mathrm{RH}$ range of $30 \%$ to $80 \%$ and $30 \%$ to $99 \%$, respectively. The growth factors range from 1.01 to 1.06 (average $1.03 \pm 0.02$ ) and from 1.02 to 1.14 (average $1.08 \pm 0.04$ ) for the single scattering albedo in the RH range of $30 \%$ to $80 \%$ and $30 \%$ to $99 \%$, respectively. The single scattering albedo is not sensitive to $\mathrm{RH}$. At a high $\mathrm{RH}$ such as $99 \%$, the single scatter albedo is close to 1.0 . The single scattering albedo and asymmetry factor are insensitive to changes in $\mathrm{RH}$. This is in agreement with those of Pilinis et al. [24]. Both scattering and extinction coefficients are more sensitive to changes in $\mathrm{RH}$ than single scatter albedo and asymmetry factor.

\subsection{The Sensitivity to Refractive Index}

In the following sensitivity studies, the parameters used for three types of aerosols are assumed to be (1) urban aerosols of Meszaros [25], N=560 cm $\mu \mathrm{m}, \mathrm{D}_{\mathrm{g}}=0.100$ $\mu \mathrm{m}, \sigma_{g}=2.0, \mathrm{~m}=1.590-0.027 i$, RH $=80 \%$; (2) continental aerosols of Hoppel et al. [24], $\mathrm{N}=3000 \mathrm{~cm}^{-3}, \mathrm{D}_{\mathrm{g}}$ $=0.080 \mu \mathrm{m}, \sigma_{g}=2.0, \mathrm{~m}=1.564-0.016 i, \mathrm{RH}=80 \%$; (3) marine aerosols of Gathman [27], $\mathrm{N}=67 \mathrm{~cm}^{-3}, \mathrm{D}_{\mathrm{g}}=0.266$ $\mu \mathrm{m}, \sigma_{g}=1.622, \mathrm{~m}=1.479-0.003 i, \mathrm{RH}=80 \%$. Note that the values of radius, refractive index in the above assumptions are for a dry state. $\mathrm{RH}$ is set to be $80 \%$ in the Mie calculation. Table 5 lists the ranges and averaged values of the change factors for the effects of real and imaginary parts of refractive index on the aerosol radiative properties. The scattering and extinction coefficients increase by about $48 \%$ and asymmetry factor decrease by $6 \%$ with real part increasing from 1.4 to 1.65 . But the single scattering albedo is insensitive to the changes in real part. Figures 3(a) and (b) show extinction coefficient and single scatter albedo as a function of real part of refractive index for three types of aerosols at a wavelength of $580 \mathrm{~nm}$. Table 5 shows that the scattering coefficient and single scattering albedo decrease by $18 \%$ and $24 \%$ when imaginary part varies from -0.005 to 0.10 , respectively. The extinction coefficient and asymmetry factor are insensitive to the change in the imaginary part. As expected, extinction coefficient and asymmetry factor increase slightly as imaginary part increases.

\subsection{The Sensitivity to Size Distributions}

As shown in Table 5, scattering and extinction coefficients are very sensitive to changes in geometric mean radius. The scattering and extinction coefficients increase by factors of 118 and 123, respectively, whereas the asymmetry factor only increases by $17 \%$ and the single scattering albedo decreases by $0.8 \%$, when the geometric mean radius varies from 0.05 to $0.3 \mu \mathrm{m}$. Figures 4(a) and (b) show the sensitivity tests for the case of marine aerosols at different wavelengths. Table 5 lists the ranges and averaged changes of radiative properties for three types of aerosols when geometric standard deviation $\left(\sigma_{g}\right)$ varies from 1.2 to 3.0. The scattering and 


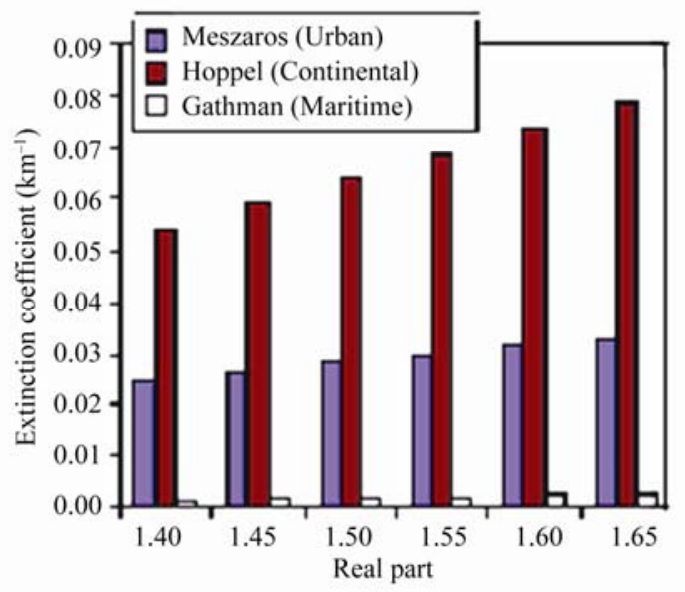

(a)

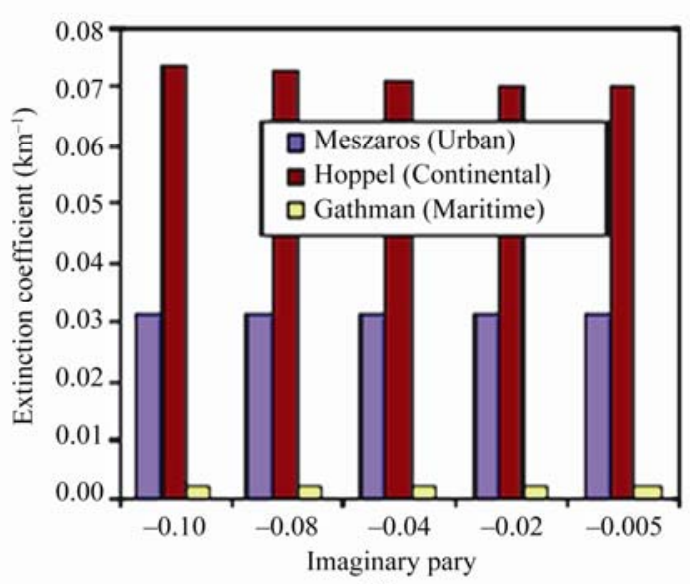

(c)

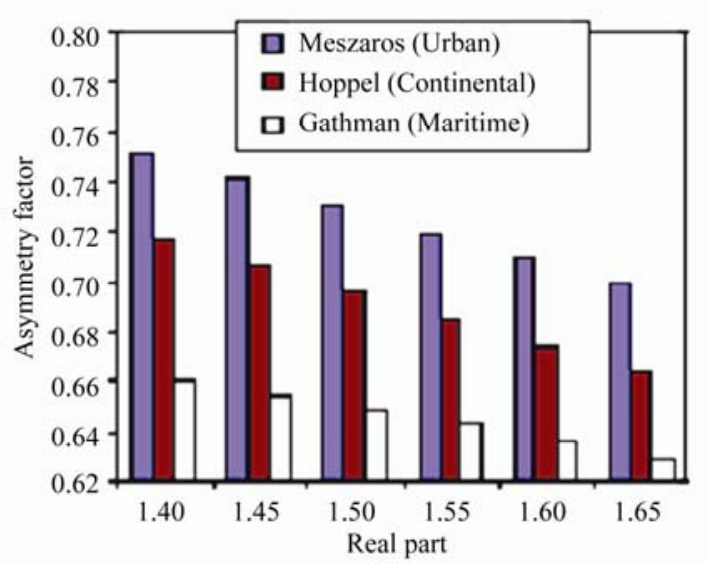

(b)

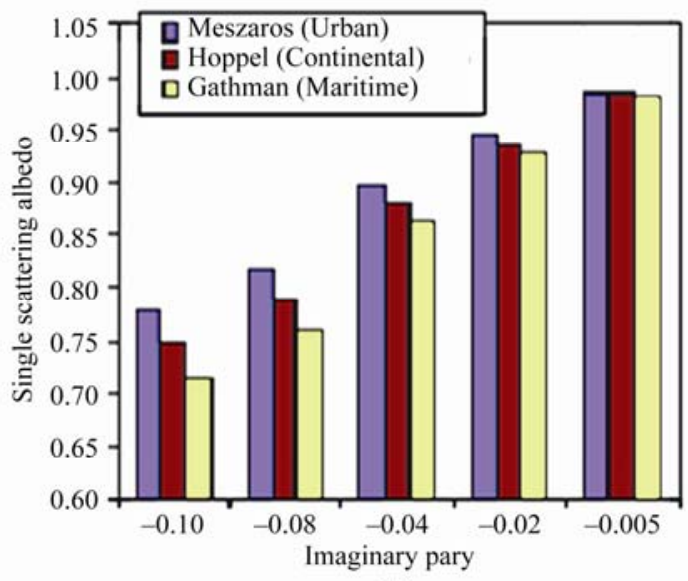

(d)

Figure 3. The radiative properties at $580 \mathrm{~nm}$ as a function of real and imaginary parts of refractive index for three types of aerosols at a dry state.

Table 5. The change factors for radiative properties of aerosols as a function of real part, imaginary part, geometric mean radius $\left(r_{g}\right)$ and geometric standard deviation $\left(\sigma_{g}\right)$. The values in parenthesis are the average change factors.

\begin{tabular}{|c|c|c|c|c|}
\hline & Real part from 1.40 to 1.65 & Imaginary part from -0.005 to -0.10 & $\mathrm{r}_{\mathrm{g}}$ from 0.05 to $0.3 \mathrm{~mm}$ & $\sigma_{g}$ from 1.20 to 3.0 \\
\hline Scattering coefficient & $1.34-1.65(1.49)$ & $0.80-0.84(0.82)$ & $51.5-248.5(118.8)$ & $153-753(389)$ \\
\hline extinction coefficient & $1.32-1.65(1.47)$ & $1.01-1.15(1.07)$ & $59.2-249.3(123.7)$ & $155-607(334)$ \\
\hline Asymmetry factor & $0.92-0.95(0.94)$ & $1.03-1.01(1.02)$ & $1.09-1.32(1.17)$ & $3.1-8.3(5.4)$ \\
\hline Single scattering albedo & $1.00-1.01(1.01)$ & $0.79-0.73(0.76)$ & $0.87-1.00(0.92)$ & $0.99-1.24(1.1)$ \\
\hline
\end{tabular}

extinction coefficients and asymmetry factor are very sensitive to the change in geometric standard deviation. The scattering and extinction coefficients increase by factors of 389.3 and 334, respectively, when geometric standard deviation varies from 1.2 to 3.0. This change of $\sigma_{g}$ results in the increase of asymmetry factor by a factor of 5.4 and the increase of single scattering albedo by 10\%. Figures 4(c) and (d) show the sensitivity of asymmetry factor and single scattering albedo to changes in $\sigma_{g}$ values for urban aerosols at different wavelengths. Figure 5(a) and (b) show the changes of the shape of aerosol size distribution when geometric mean radius varies from 0.1 to $0.4 \mu \mathrm{m}$ at $\mathrm{N}_{0}=560 \mathrm{~cm}^{-3}$ and $\sigma_{g}=2.0$ and when geometric standard deviation varies from 1.2 to 3.0 at $\mathrm{N}_{0}=560 \mathrm{~cm}^{-3}$ and $\mathrm{r}_{\mathrm{g}}=0.15 \mu \mathrm{m}$, respectively. Since the light scattering efficiency of an individual particle is dependent on the particle size, with peak efficiencies occurring between $\sim 0.2$ and $0.7 \mu \mathrm{m}$ in particle radius for a light wavelength of $580 \mathrm{~nm}$, aerosol particles can have large scattering and extinction coefficients if their size distributions grow into this efficient light scattering size range. Figure 5 indicates that both cases can result 


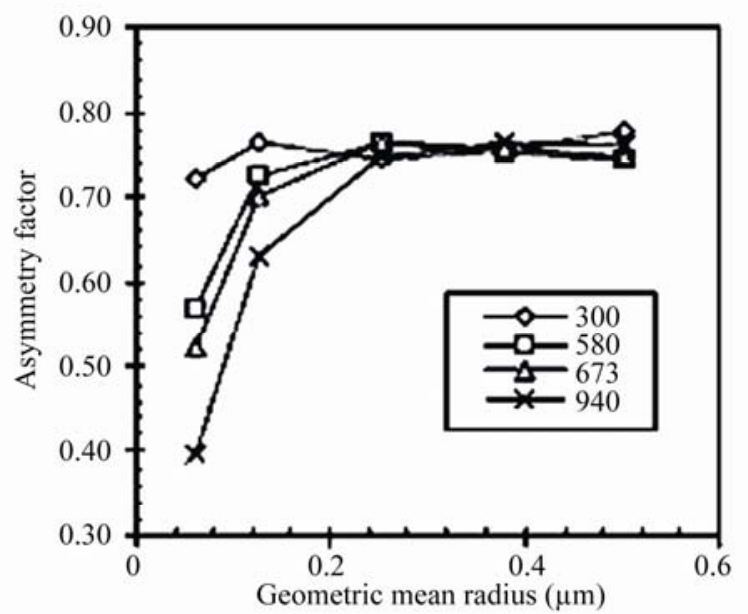

(a)

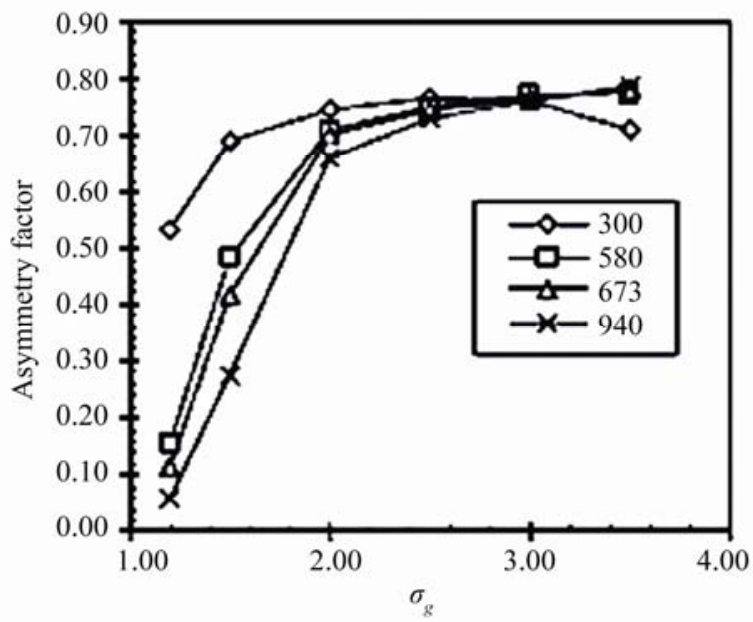

(c)

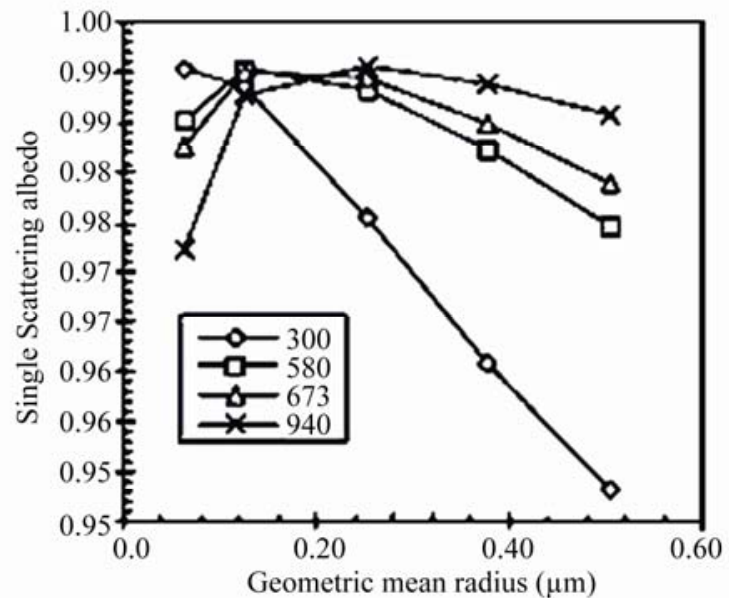

(b)

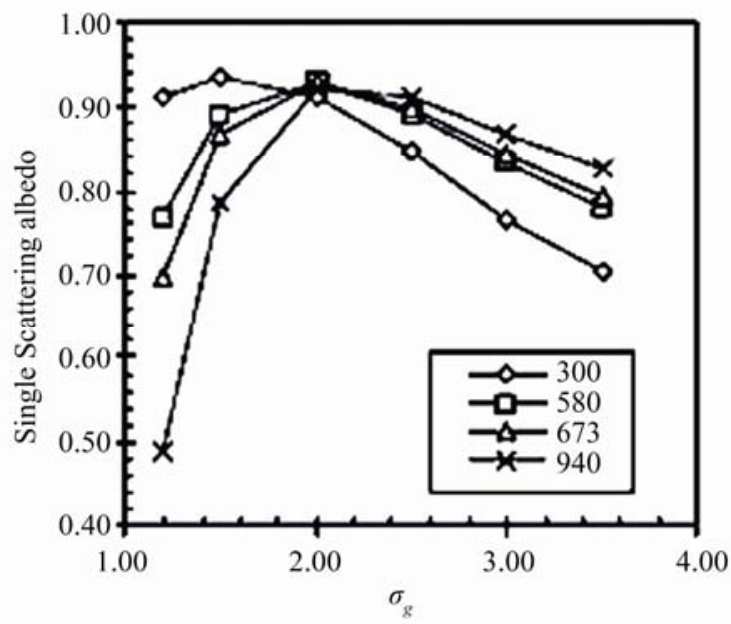

(d)

Figure 4. The radiative properties at $580 \mathrm{~nm}$ as a function of geometric mean radius (for Gathma's maritime aerosols (a, b), and geometric standard deviation (for Meszaros' urban aerosols (c, d)).



(a)

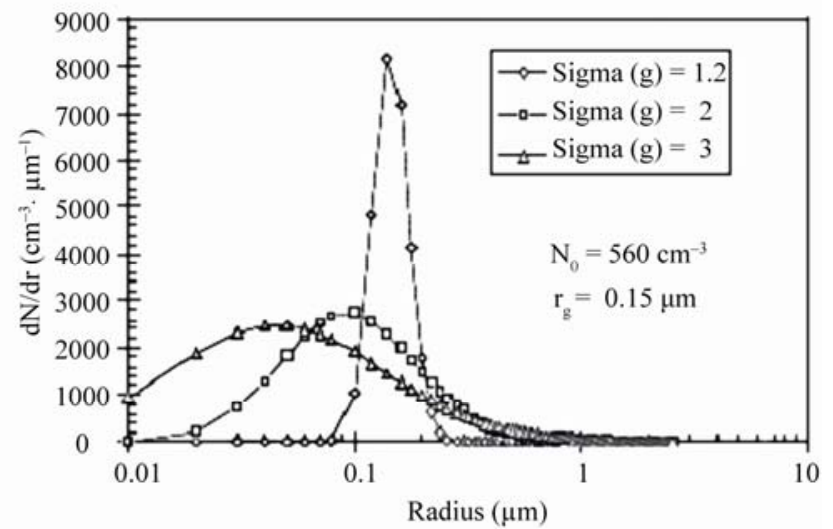

(b)

Figure 5. The size distribution of aerosol number concentration as a function of geometric mean radius (a) and standard deviation (b). 
in more particles in the efficient light scattering size range (with radii of 0.2 to $0.7 \mu \mathrm{m}$ ). It is not surprised to find that the scattering and extinction coefficients are very sensitive to the changes in geometric mean radius and geometric standard deviation.

\subsection{The Sensitivity of Wavelength Dependence of Radiative Properties}

The wavelength dependence of aerosol radiative properties is very sensitive to geometric mean radius. When the geometric mean radius is small, both single scattering albedo and asymmetry factor decrease with increasing wavelengths, but when the geometric mean radius becomes larger than a value, both single scattering albedo and asymmetry factor increase with increasing wavelengths. For the latter case, the Angstrom law will not be applicable. The values of geometric mean radii at the crossing point are different for asymmetry factor and single scattering albedo as shown in Figures 4(a) and (b), and are also determined by the geometric standard deviation as analyzed below. Since the light scattering efficiency of an individual particle is a nonlinear function of particle size and depends on the particle size and light wavelength tested, and the refractive index is wavelength dependent, the wavelength dependence of aerosol radiative properties will strongly rely on the size distribution and refractive index. For the wavelength dependence of refractive index, available data were closely matched by setting $\mathrm{n}(\lambda)=\mathrm{n}(\lambda=0.598 \mu \mathrm{m})-0.03(\lambda-0.598)$, where $\lambda$ is the wavelength in $\mu \mathrm{m}$. As shown, the wavelength dependence of refractive index is weak. As shown in Figure 4, the wavelength dependence of asymmetry factor and single scattering albedo strongly relies on the geometric mean radius and geometric standard deviation. But the wavelength dependence of scattering and extincttion coefficients on the geometric mean radius and geo- metric standard deviation is weak. For small geometric mean radius and small geometric standard deviation, both asymmetry factor and single scattering albedo increase with decreasing wavelengths, however, for large values of geometric mean radius and geometric standard deviation, both asymmetry factor and single scattering albedo increase with increasing wavelengths, especially for single scattering albedo, as shown in Figure 4.

\subsection{Radiation Transmission}

Since human-induced aerosols are likely to greatly influence future regional climate change instead of global climate change, it is of interest to examine the sensitivity of the aerosol-induced radiation transmission changes at a local or regional scale to aerosol composition, size distributions, and RH. In this study, the radiation transmission is calculated for the assumed aerosol layer with a depth of 2 kilometers using the Madronich's Tropospheric Ultraviolet-Visible Radiation Transfer Model (TUVRTM) [28]. The optical depth $\tau=\int_{z_{1}}^{z_{2}} \sigma_{e}(z) \mathrm{d} z$ is calculated by assuming a constant extinction coefficient within the aerosol layer. The sensitivity of aerosol-induced radiation transmission changes at $580 \mathrm{~nm}$ is examined under the following constant conditions: date = $7 / 01 / 1995, \mathrm{O}_{3}=278 \mathrm{DU}$, ground albedo $=0.15$, air pressure $=940 \mathrm{mb}$, Latitude $=35.63^{\circ}$, longitude $=82.33^{\circ}$, UT $=17.90$, solar zenith angle $=13.31$, the aerosol layer $=2$ $\mathrm{km}$. Three aerosol radiative properties (optical depth, asymmetry factor, and single scattering albedo) are needed in the TUVRTM model to calculate the aerosol-induced radiation transmission changes. In this section, the sensitivity of the aerosol-induced radiation transmission change to $\mathrm{RH}$, refractive index, and size distribution is studied based on previous calculation re-

Table 6. The radiation transmission at $580 \mathrm{~nm}$ calculated by a radiative transfer model for different aerosol types assuming an aerosol layer of $2 \mathrm{~km}$. The date is $7 / 1 / 1995, \mathrm{O}_{3}=278 \mathrm{DU}$, latitude $=35.63^{\circ}$, longitude $=-82.33^{\circ}, \mathrm{UT}=17.90$, zenith angle $=$ $13.31^{\circ}$.

\begin{tabular}{|c|c|c|c|c|c|c|c|c|c|}
\hline \multirow[b]{2}{*}{ Spectrum } & \multirow[b]{2}{*}{ Aerosol types } & \multicolumn{3}{|c|}{ Accumulation mode } & \multicolumn{3}{|c|}{ Transmission at $580 \mathrm{~nm}$} & \multirow[b]{2}{*}{$\mathrm{T}_{2} / \mathrm{T}_{1}$} & \multirow[b]{2}{*}{$\mathrm{T}_{3} / \mathrm{T}_{1}$} \\
\hline & & $\mathrm{n}\left(\mathrm{cm}^{-3}\right)$ & $\mathrm{D}_{\mathrm{g}}(\mu \mathrm{m})$ & $\sigma_{g}$ & $\mathrm{~T}_{1}(\mathrm{RH}=30)$ & $\mathrm{T}_{2}(\mathrm{RH}=80)$ & $\mathrm{T}_{1}(\mathrm{RH}=99)$ & & \\
\hline Meszaros [23] & Urban & 560 & 0.1 & 2 & 0.908 & 0.908 & 0.906 & 1 & 1 \\
\hline Whitby [28] & Continental & 2300 & 0.076 & 2 & 0.906 & 0.906 & 0.890 & 1 & 0.98 \\
\hline Hoppel et al [24] & Continental & 3000 & 0.08 & 2 & 0.904 & 0.895 & 0.840 & 0.99 & 0.93 \\
\hline Leaitch and Isaac [29] & Continental & 1000 & 0.24 & 1.35 & 0.897 & 0.895 & 0.844 & 1 & 0.94 \\
\hline Jenning et al [30] & $\begin{array}{l}\text { Continental- } \\
\text { marine mixture }\end{array}$ & 950 & 0.2 & 1.35 & 0.904 & 0.903 & 0.876 & 1 & 0.97 \\
\hline Gathman [25] & Maritime & 67 & 0.266 & 1.62 & 0.911 & 0.911 & 0.911 & 1 & 1 \\
\hline Jaenicke and Schutz [31] & Polar aerosol & 18.6 & 0.75 & 2 & 0.910 & 0.911 & 0.911 & 1 & 1 \\
\hline Background & $\begin{array}{l}\text { without aerosol } \\
\text { layer }\end{array}$ & 0 & 0 & 0 & 0.911 & 0.911 & 0.911 & & \\
\hline
\end{tabular}


Table 7. The change factors for radiation transmission at $580 \mathrm{~nm}$ as a function of relative humidity and radiative properties for three types of aerosols.* The average is calculated only for urban and continental aerosols.

\begin{tabular}{|c|c|c|c|c|}
\hline \multirow[b]{2}{*}{ Parameter } & \multicolumn{4}{|c|}{ Aerosol type } \\
\hline & Urban & Continental & Marine & average* \\
\hline Relative humidity from 0 to $95 \%$ & 0.999 & 0.993 & 1 & 0.996 \\
\hline Real part from 1.40 to 1.65 & 0.998 & 0.992 & 1 & 0.995 \\
\hline Imaginary part from -0.005 to -0.10 & 0.979 & 0.967 & 0.998 & 0.973 \\
\hline Number concentrations from 50 to $4000 \mathrm{~cm}^{-3}$ & 0.94 & 0.977 & 0.977 & 0.958 \\
\hline $\mathrm{r}_{\mathrm{g}}$ from 0.05 to $0.30 \mu \mathrm{m}$ & 0.467 & 0.022 & 0.99 & 0.244 \\
\hline$\sigma_{g}$ from 1.2 to 3.0 & 0.934 & 0.831 & 0.997 & 0.883 \\
\hline
\end{tabular}
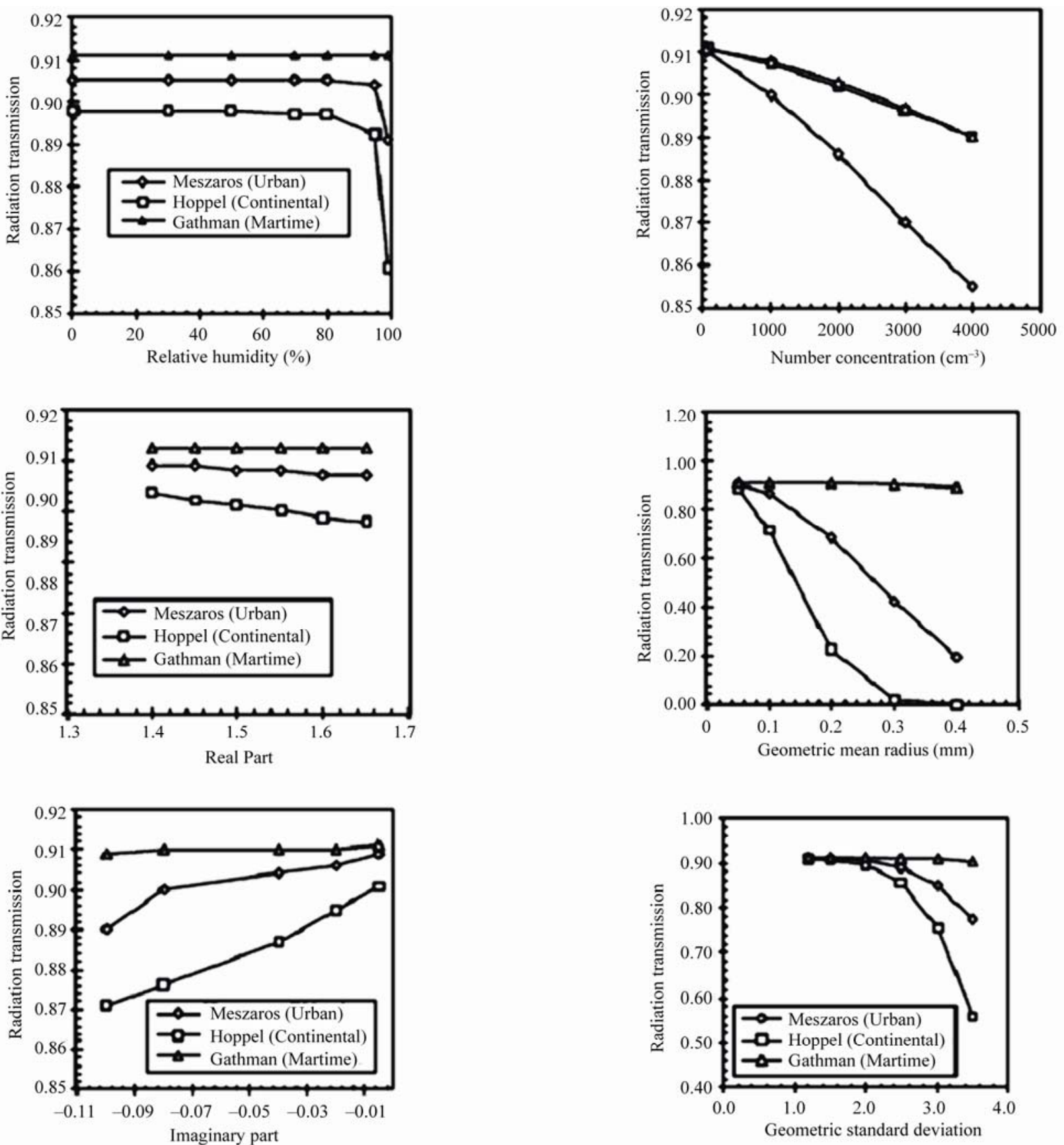

Figure 6. The radiation transmission at $580 \mathrm{~nm}$ across an aerosol layer with a 2-km in depth as a function of $\mathrm{RH}$, real and imaginary parts, number concentration, and size distribution for three types of aerosols. 
sults of aerosol radiative properties for the three types of aerosols. Table 6 lists the radiation transmissions at 580 $\mathrm{nm}$ for different aerosol types at RHs of 30\%, $80 \%$ and 99\%. Figure 6 shows the sensitivity of radiation transmission to $\mathrm{RH}$, refraction index, number concentrations and size distributions for the three types of aerosols. Table 7 lists the change factors for radiation transmission for three types of aerosols. Note that the radiation transmission at $580 \mathrm{~nm}$ is 0.911 without the aerosol layer under the assumed atmospheric conditions. It is interesting to note that the radiation transmission is not sensitive to the changes in the above parameters if the total aerosol number concentration is small as it for maritime aerosols of Gathman [27] (total number concentration is only 67 $\mathrm{cm}^{-3}$ as indicated in Table 7). In this case, the radiation transmission only decreases by $0.4 \%$ and $0.5 \%$ when $\mathrm{RH}$ varies from $0 \%$ to $95 \%$ and the real part varies from 1.40 to 1.65 , respectively. The radiation transmission is sensitive to the change in imaginary part and number concentrations with the decrease of visible radiation transmission by $2.7 \%$ and $4.2 \%$ when the imaginary part varies from -0.005 to -0.1 and number concentration from 50 to $4000 \mathrm{~cm}^{-3}$, respectively. The radiation transmission is very sensitive to the changes in geometric mean radius and geometric standard deviation. The radiation transmission decreases by $76 \%$ when geometric mean radius varies from 0.05 to $0.3 \mu \mathrm{m}$ and decreases by $12 \%$ when geometric standard deviation varies from 1.2 to 3.0. This is in agreement with the strong dependence of scattering and extinction coefficients on geometric mean radius and geometric standard deviation. It should be emphasized that the radiation transmission also strongly depends on the solar zenith angle, latitude and longitude, and ozone concentrations.

\section{Conclusions}

In this work, the partial molar refraction method is used to accurately calculate the real part of refractive index of aerosol particles with actual measured chemical compositions including soluble inorganic and organic ions and insoluble inorganic and organic substances. It is found that the complex refractive indices for urban, continental and marine aerosols are $1.575-0.027 i, 1.557-0.016 i$ and $1.479-0.003 i$, respectively. The scattering and extinction coefficients are sensitive to changes in RH, while both single scattering albedo and asymmetry factor are insensitive to change in $\mathrm{RH}$. The extinction coefficient and asymmetry factor are sensitive to changes in real part of refractive index. The scattering coefficient and single scattering albedo are sensitive to the imaginary part changes. The aerosol radiative properties are very sensitive to the change in both geometric mean ra- dius and geometric standard deviation of a particle size distribution. The radiation transmission decreases by $76 \%$ and $12 \%$ when geometric mean radius varies from 0.05 to $0.3 \mu \mathrm{m}$ and geometric standard deviation varies from 1.2 to 3.0 , respectively. Other sensitivities for the radiation transmissions are insignificant. The comparison between theoretical calculation and actual measurement will be necessary in the future work.

\section{References}

[1] R. J. Charlson, S.E. Schwartz, J. M. Hales, R. D. Cess, J. A. Coakley, J. E. Hansen and D. J. Hofmann, "Climate Forcing by Anthropogenic Aerosols," Science, Vol. 225, 1992, pp. 423-430. doi:10.1126/science. 255.5043 .423

[2] S. C. Yu, "The Role of Organic Acids (Formic, Acetic, Pyruvic and Oxalic) in the Formation of Cloud Condensation Nuclei (CCN): A Review," Atmospheric Research, Vol. 53, 2000, pp. 185-217. doi:10.1016/S0169-8095(00)00037-5

[3] S. C. Yu, V. K. Saxena and Z. Zhao, "A Comparison of Signals of Regional Aerosol-Induced Forcing in Eastern China and the Southeastern United States," Geophysical Research Letters, Vol. 28, 2001, pp. 713-716. doi:10.1029/2000GL011834

[4] Intergovernmental Panel on Climate Change (IPCC), "Climate Change 2007: The Physical Science Basis," Contribution of Working Group I to the Fourth Assessment Report of the Intergovernmental Panel on Climate Change, Cambridge University Press, New York, 2007.

[5] J. E. Penner, R. J. Charlson, J. M. Hales, N. S. Laulainen, R. Leifer, T. Novakov, J. Ogren, L. F. Radke, S. E. Schwartz and L. Travis, "Quantifying and Minimizing Uncertainty of Climate Forcing by Anthropogenic Aerosols," Bulletin of the American Meteorological Society, Vol. 75, 1994, pp. 375-400.

doi:10.1175/1520-0477(1994)075<0375:QAMUOC $>2.0$. $\mathrm{CO} ; 2$

[6] O. Boucher and T. L. Anderson, "General Circulation Model Assessment of The Sensitivity of Direct Climate Forcing by Anthropogenic Sulfate Aerosols to Aerosol Size and Chemistry," Journal of Geophysical Research, Vol. 100, 1995, pp. 26117-26134. doi:10.1029/95JD02531

[7] M. Z. Jacobson, "Global Direct Radiative Forcing Due to Multicomponent Anthropogenic and Natural Aerosols," Journal of Geophysical Research, Vol. 106, 2001, pp. 1551-1568. doi:10.1029/2000JD900514

[8] D. Koch, S. Bauer, A. Del Genio, G. Faluvegi, J. R. McConnell, S. Menon, R. L. Miller, D. Rind, R. Ruedy, G. A. Schmidt and D. Shindell, "Coupled Aerosol-Chemistry-Climate Twentieth Century Transient Model Investigation: Trends in Short-Lived Species and Climate Responses," Journal of Climate, 2011.

[9] W. F. Rogge, M. A. Mazurek, L. M. Hildemann, G. R. Cass and B. R. T. Simoneit, "Quantification of Urban 
Organic Aerosols at a Molecular Level: Identification, Abundance and Seasonal Variation," Atmospheric Environment, Vol. 27, 1993, pp. 1309-1330.

[10] G. Hänel, "The Properties of Atmospheric Aerosol Particles as Functions of Relative Humidity at Thermodynamic Equilibrium with the Surrounding Air," Advances in Geophysics, Vol. 19, 1976, pp. 73-188. doi:10.1016/S0065-2687(08)60142-9

[11] R. F. Pueschel, "Atmospheric Aerosols," In: Singh H. B.,Van Nostrand Reinhold, Eds., Composition, Chemistry and Climate of the Atmsopher, 1995, pp. 120-175.

[12] P. Chylek and J. Wong, "Effect of absorbing aerosols on global radiation budget, Geophysical Research Letters, Vol. 22, No. 8, 1995, pp. 929-931. doi:10.1029/95GL00800

[13] J. J. Huntzicker, R. L. Johnson, J. J. Shah and R. A. Cary, "Analysis of Organic and Elemental Carbon in Ambient Aerosols by a Thermal-Optical Method," In: Particulate Carbon: Atmospheric Life Using a Particle Trap Impactor/Denuder Sampler, Environmental Science \& Technology, Vol. 35, No. 24, 1982, pp. 4857-4867.

[14] A. W. Stelson, "Urban Aerosol Refractive Index Prediction by Partial Molar Refraction Approach," Environmental Science \& Technology, Vol. 24, 1990, pp. 1676-1679. doi:10.1021/es00081a008

[15] R. C. Weast, CRC Handbook of Chemical and Physics, Cleveland, OH, 1988.

[16] F. Volz, "Infrared Absorption by Atmsopheric Aerosol Substances," Journal of Geophysical Research, Vol. 77, 1972, pp. 1017-1031. doi:10.1029/JC077i006p01017

[17] C. S. Sloane, "Optical properties of aerosols of mixed composition," Atmospheric Environment, Vol. 18, 1984, pp. 871-878. doi:10.1016/0004-6981(84)90273-7

[18] I. N. Tang, W. T. Wong and H. R. Munkelwiz, "The Relative Importance of Atmospheric Sulfates and Nitrates in Visibility Reduction," Atmospheric Environment, Vol. 15, 1981, pp. 2463-2471. doi:10.1016/0004-6981(81)90062-7

[19] H. Horvath, "Atmospheric Light Absorption - a Review," Atmospheric Environment, Vol. 27, 1993, pp. 293-317.

[20] G. W. Grams, I. H. Blifford, D. A. Gillette and P. B. Russell, "Complex Index of Refraction of Airborne Soil Particles," Journal of Applied Meteorology, Vol. 13, 1974, pp. 459-471. doi:10.1175/1520-0450(1974)013<0459:CIOROA $>2.0 . \mathrm{C}$ $\underline{\mathrm{O} ; 2}$

[21] J. V. Dave, "Subroutines for Computing the Parameters of Electomagnetic Radiation Scattered by a Sphere," IBM
Journal of Research and Development, Vol. 13, 1969, pp. 302-312. doi:10.1147/rd.133.0302

[22] R. J. Charlson, D. S. Covert and T. V. Larson, “Observations of the effect of humidity on light scattering by aerosols," In: Ruhnke T. H. and Deepak A., Eds., Hygroscopic Aerosols, pp. 35-44, Hampton, VA, 1984.

[23] D. Hegg, T. Larson and P. F. Yuen, "A Theoretical Study of the Effect of Relative Humidity on Light Scattering by Tropospheric Aerosols," Journal of Geophysical Research, Vol. 98, 1993, pp. 18435-18439. doi:10.1029/93JD01928

[24] C. Pilinis, S. N. Pandis and J. H. Seifeld, "Sensitivity of Direct Climate Forcing by Atmospheric Aerosols to Aerosol Size and Composition," Journal of Geophysical Research, Vol. 100, 1995, pp. 18739-18754. doi:10.1029/95JD02119

[25] A. Meszaros, "On the Concentration and Size Distribution of Atmospheric Sulfate Particles under Rural Conditions," Atmospheric Environment, Vol. 12, 1978, pp. 2425-2428. doi:10.1016/0004-6981(78)90286-X

[26] W. A. Hoppel, R. Larson and M. A. Vietti, "Aerosol Size Distributions at a Site on the East Coast of the United States," Atmospheric Environment, Vol. 18, 1984, pp. 1613-1621. doi:10.1016/0004-6981(84)90383-4

[27] S. C. Gathman, "Optical Properties of the Maritime Aerosols as Predicted by the Navy Aerosol Model," $\mathrm{Op}$ tical Engineering, Vol. 22, 1983, pp. 56-62.

[28] S. Madronich, "Tropospheric Photochemistry and Its Response to UV Changes," In: M. L. Chanin, Ed., The role of the stratosphere in global change, NATO-ASI Series, Vol. 18, pp. 437-461, Springer-Verlag, Amsterdam, 1993.

[29] E. A. Moelwyn-Hughes, Physical Chemistry, 2nd rev. ed., Pergamon Press, New York, 1961.

[30] K. T. Whitby, "The Physical Characteristics of Sulfur Aerosols," Atmospheric Environment, Vol. 12, 1978, pp. 135-159. doi:10.1016/0004-6981(78)90196-8

[31] W. R. Leaitch and G. A. Isaac, "Tropospheric Aerosol Size Distributions from 1982 to 1988 over Eastern North America," Atmospheric Environment, Vol. 25, 1991, pp. 601-619.

[32] S. G. Jennings, C. D. O’Dowd, T. C. O'Connor and F. M. McGovern, "Physical Characteristics of Ambient Aerosol at Mace Head," Atmospheric Environment, Vol. 25A, 1991, pp. 557-562.

[33] R. Jaenicke and L. Schiitz, "Arctic Aerosol in Surface Air," ldoyaras 86, 1982235-241. 